\title{
6 Informal trader associations in Tanzania - providing limited but much-needed informal social protection
}

\author{
Lone Riisgaard
}

\section{Introduction}

Micro-trade is a dominant activity in the informal economy in most urban areas of the global south. In Tanzania, it provides a very relevant context for studying the access that people in the informal economy have to both formal and informal social protection mechanisms - insights that are essential in light of the ongoing expansion of formal social protection in Tanzania and SubSaharan Africa more broadly. As described in more detail in the introduction to this edited volume, social protection policies and instruments have gained increasing attention among many countries, including Tanzania. Many partners, including donors, have since the late 1980 viewed social protection as the preferred solution to issues of poverty in the global South (Deacon, 2013; Hickey \& Seekings, 2017; Hickey et al., 2019).

In Tanzania, recent years have seen attempts at expanding informal workers' access to social protection such as pension and insurance schemes. Nonetheless, as illustrated in this chapter, formal social protection is still largely beyond the reach of informal traders, a gap which informal traders' associations seek to fill with a variety of different services. They, for example, cushion members in cases of death or medical problems in the family and represent members' interests towards authorities.

In this chapter, we investigate the access that informal micro-traders in Tanzania have to formal and informal social protection measures. The key challenges they face and how (and if) these challenges are addressed by formal social protection measures and by the informal social protection measures employed by their own collective associations are discussed. Consequently, the chapter provides insights into how micro-traders - who work in one of the most common and vulnerable informal occupations - organize and how (if at all) they access social protection. By comparing Dodoma's setting with Dar es Salaam, which is predominantly urban, we also seek to address differences (if any exist) which might be related to the degree of urbanization.

A broad understanding of social protection is adopted, encompassing formal social insurance programmes such as health insurance or maternity leave as well as informal cushioning mechanisms, access to micro-finance and training, and representation and voice. However, narrowly targeted safety net measures 
(commonly known as social assistance) are not covered since they are mostly not offered by informal associations.

The chapter employs a broad understanding of the informal economy, including self-employment in informal enterprises (i.e. unregistered or unlicenced business), as well as wage employment in informal jobs without a written contract. As discussed in more detail in Chapter 1 of this edited volume, informality is a highly politicized concept which often appears in degrees while intersecting with formality in various ways. Informal traders might, for example, sell goods on commission for formally registered retailers while working either in formally designated vending areas or in informal ones. Nonetheless, informality remains an essential concept in terms of delimitating social protection rights for workers.

The chapter draws on Nvivo-processed data from focused group discussions (FDGs) and key informant interviews (KIIs) with micro-traders and their associations carried out between April 2018 and January 2019. ${ }^{1}$ Four FGDs were conducted, representing a total of 13 different associations in Dodoma and 16 in Dar es Salaam. Furthermore, nine KIIs were conducted with association leaders in Dodoma and 12 in Dar es Salaam. In total, more than 40 different associations were represented. The paper also draws on survey data on micro-traders in Dodoma and Dar es Salaam. The survey was carried out in 2018 and used a combination of purpose-based sampling and random selection. Of the 286 survey interviews conducted with micro-traders, 62 percent were sampled geographically while 38 percent were sampled via a variety of informal worker associations (where the target group were ordinary members) to ensure a broad coverage of different types of associations. ${ }^{2}$

The findings are indicative of the collective organization and access to social protection amongst micro-traders in urban areas and, in particular, the more vulnerable segment of micro-traders. We focused on traders who were mobile and/or working in a space without a fixed structure even though a few KII and FGD participants did come from established markets. Most often, their work is characterized by low entry barriers, high competition, and low and irregular incomes. They generally have no officially recognized space of work and face frequent harassment in environments which lack essential facilities such as clean water, waste disposal, and storage facilities.

In the remainder of this chapter, we start by examining how informal trade is governed in Tanzania, and relatedly, how informal traders are organizing collectively; we then explore the challenges faced by micro-traders and their access to formal social protection mechanisms; followed by discussion of how micro-traders are organized and the services associations offer to their members. Using the Power Resource Approach (PRA; Schmalz, Ludwig \& Webster, 2018), the power resources available to associations are analyzed along with their access barriers. We then compare traders who enrol in informal associations to those who do not belong to any associations. The final section concludes on the findings and the overall comparison between informal social protection mechanisms and official ones. 


\section{Lone Riisgaard}

\section{Collective organization and the governance of micro-traders}

Attitudes and policies towards informal micro-traders have varied over time. In Dar es Salaam, local by-laws from the 1960s and 1970s made micro-trading illegal, but the 1980s economic crisis resulted in some accommodation such as the establishment of municipal licences for mobile traders in 1983 (Brown, Lyons \& Dankoco, 2009; Brown et al., 2015). In general, a more participatory approach to city planning was initiated where the local government in Dar es Salaam encouraged representation of informal workers' associations at the ward level, and by 1997, some 240 self-help groups had been formed (Brown, Lyons \& Dankoco, 2009).

Since 2003, however, the participatory line has been reversed. In 2003, the peddlers' licence was cancelled, rendering street traders illegal (Lyons \& Msoka, 2010), and in 2006, the Prime Minister instructed local authorities to move street traders from busy areas, leading to widespread clearances (Lyons \& Msoka, 2010). Evictions have been and still are common, although often relocation has been unsuccessful as the new localities have failed to attract customers.

Tanzania has a long tradition of traders' associations and other informal networks which was intensified by the post-independence norms of socialism and self-reliance (Brown, Lyons \& Dankoco, 2009). Associations are commonly known by the Swahili word kikundi (plural: vikundi) and are often welfareoriented, multi-ethnic, run by contributions from members and have elected officers (Tsuruta, 2006).

In addition to trade associations are the trade unions, which historically have been relatively weak in Tanzania, as the ruling party has sought to control independent sources of power (Tripp, 2000). The autonomy of the trade unions increased with the reintroduction of a multi-party system in the early 1990s; nonetheless, trade unions in Tanzania are still swaying between continued control by the ruling party and efforts to establish themselves as autonomous organizations (Fisher, 2011).

The trade union movement in Tanzania has only within the last decade or so begun to show an interest in organizing informal workers (Fisher, 2011). In a context of declining trade union membership, trade unions in Tanzania are taking new measures to include people in the informal economy as part of the trade union constituency. Lacking any strategy on the matter from the federation level, very few unions are yet to succeed in recruiting substantial numbers of informal members. Only the unions representing transport workers, domestic workers, and commercial workers are actively pursuing membership of informal workers. This is often in cooperation with labour-oriented NGOs and international or developed country unions which now have inclusion of the informal economy as a top priority.

Since the late 1990s, governments have tried to formalize informal activities with the aim of enabling small informal enterprises to participate in and benefit from the market economy (Brown, Lyons \& Dankoco, 2009). An example 
is the 2006 World Bank-supported 'Doing Business' programme. It assumed that micro-entrepreneurs such as informal traders would benefit from reduced bureaucracy and in particular to property and business rights and increased access to credit (Lyons, Brown \& Msoka, 2014). However, as shown by Lyons, Brown, and Msoka (2014), very few licence categories have been available for micro-traders and to obtain a business licence, one needs to have a fixed and legal address. Hence, the requirements demanded to formalize cannot be met by most micro-traders.

The strong focus on formalization gives the impression that informal activities are undesired and something to be overcome in order to achieve a modern market-driven economy. Discourses, however, change, and the late president Magufuli advocated a stop to harassment of informal traders. Hence, many small traders were able to paraphrase the president as illustrated by one street vendor: "The president said no eviction of these people. Leave them to work. You should make arrangement of how they will work in the streets" (FGD, Dar es Salaam). The more positive attitude expressed by the president has gone together with a massive effort of registration of individual traders, along with what resembles a new form of taxation.

Since December 2017, a total of 670,000 IDs (popularly called Magufuli cards) have been distributed to micro-traders with business capital not exceeding four million TZS (1,769 USD) per annum (Tanzania Daily News 02.01.2018, The East African 15.12.2018). The total value of the IDs (at 20,000 TZS each/9 USD) is 13.4 billion TZS (6.03 million USD). ${ }^{3}$ All revenue from the new ID cards goes to the central government, and hence they have been criticized for diverting revenue away from the local governments who are still responsible for servicing the areas where the micro-traders work - but are no longer supposed to collect trading fees. ${ }^{4}$ The new ID so far seems to have been generally well received by micro-traders, although it is somewhat unclear what they get from having this card.

In sum, authorities have had, and still have, an ambivalent relation with informal traders. Approaches alternate between tolerance and evictions, often following election cycles, as politicians ask local authorities to go easy on informal traders until the election is over (see e.g. Babere, 2013). Despite the new IDs, micro-traders have very few rights in public space, and if found guilty of trading in unsanctioned areas, they face a fine of TZS 50,000 (USD 21.90). ${ }^{5}$ Meanwhile, efforts at formalizing the informal economy - at the moment predominantly via registration and relocation - continue.

\section{Characteristics of micro-traders}

The micro-traders in Dar es Salaam and Dodoma form a heterogeneous group. They all provide cheap goods and service but occupy very different positions in the economy depending on what they sell and whether they work in designated or undesignated areas. Of the 286 micro-traders participating in the survey, the average age was 35 years, and 56 percent were female. The educational level 


\section{Lone Riisgaard}

varies quite a lot but, perhaps tellingly, less than a quarter had above primary level education (Table 6.1). These figures are in line with those reported for the informal economy in the 2014 Labour Force Survey (ILFS, 2015).

The heterogeneity of informal traders is illustrated in the assets they own. As seen in Table 6.1, 42 percent of the survey respondents (or their spouse) own a plot of land or property while 15 percent own other assets. ${ }^{6}$ An equal amount (43 percent), however, do not possess any assets. The median daily wage listed in Table 6.1 also hides large differences. As seen in Table 6.2 below, there is a large difference between the 10th and the 90th percentiles (1 USD versus 17.5 USD daily); however, 75 percent earn 7.66 USD or less per day.

Table 6.1 Key worker characteristics

\begin{tabular}{|c|c|c|c|c|c|c|c|}
\hline & \multicolumn{3}{|c|}{ Tanzania $N=286$} & \multicolumn{2}{|c|}{$\begin{array}{l}\text { Dar es Salaam N } \\
=134\end{array}$} & \multicolumn{2}{|c|}{ Dodoma $N=152$} \\
\hline & Sum & Mean & $\begin{array}{l}\text { Std. } \\
\text { Deviation }\end{array}$ & Mean & $\begin{array}{l}\text { Std. } \\
\text { Deviation }\end{array}$ & Mean & $\begin{array}{l}\text { Std. } \\
\text { Deviation }\end{array}$ \\
\hline $\begin{array}{l}\text { Association } \\
\text { member* }\end{array}$ & & 0.34 & 0.47 & 0.33 & 0.42 & 0.34 & 0.48 \\
\hline $\begin{array}{l}\text { Formal insurance } \\
\text { enrolment } \\
\text { (health/ } \\
\text { pension) }\end{array}$ & 57 & 0.20 & 0.40 & 0.09 & 0.29 & 0.30 & 0.46 \\
\hline $\begin{array}{l}\text { Health insurance } \\
\text { coverage }\end{array}$ & 64 & 0.22 & 0.42 & 0.13 & 0.33 & 0.31 & 0.46 \\
\hline $\begin{array}{l}\text { Gender (male } \\
=1 \text { ) }\end{array}$ & 127 & 0.44 & 0.50 & 0.53 & 0.50 & 0.37 & 0.48 \\
\hline Age & & 34.85 & 11.19 & 36.04 & 11.82 & 33.8 & 10.53 \\
\hline Married & 162 & 0.57 & 0.50 & 0.55 & 0.50 & 0.58 & 0.50 \\
\hline Local born & 134 & 0.47 & 0.50 & 0.25 & 0.43 & 0.66 & 0.48 \\
\hline $\begin{array}{c}\text { Mean daily } \\
\text { earnings } \\
\text { (current } \\
\text { USD)** }\end{array}$ & & 7.87 & 13.83 & 8.46 & 12.15 & 7.36 & 15.06 \\
\hline $\begin{array}{l}\text { Assets (house } \\
\text { and/or land) }\end{array}$ & 119 & 0.42 & 0.50 & 0.34 & 0.48 & 0.48 & 0.50 \\
\hline $\begin{array}{l}\text { Primary } \\
\text { incomplete }\end{array}$ & 38 & 0.13 & 0.34 & 0.1 & 0.30 & 0.16 & 0.37 \\
\hline $\begin{array}{l}\text { Primary } \\
\text { complete }\end{array}$ & 183 & 0.64 & 0.48 & 0.69 & 0.47 & 0.6 & 0.49 \\
\hline $\begin{array}{l}\text { Secondary or } \\
\text { above }\end{array}$ & 65 & 0.23 & 0.42 & 0.22 & 0.41 & 0.24 & 0.43 \\
\hline Wage-worker & 16 & 0.06 & 0.23 & 0.05 & 0.22 & 0.06 & 0.24 \\
\hline Own-account & 223 & 0.78 & 0.42 & 0.82 & 0.39 & 0.74 & 0.44 \\
\hline Micro-business & 46 & 0.16 & 0.37 & 0.13 & 0.33 & 0.19 & 0.39 \\
\hline
\end{tabular}

Source: Author's elaboration based on project survey data.

Notes: Summary statistics based on the full sample. * Association member figures are from the random sample where $\mathrm{N}=179, \mathrm{~N}=89$, and $\mathrm{N}=90$ respectively. ${ }^{*}$ Due to the large standard deviation and the large difference between the mean and median values, the median value 3.72 USD is thought to be a more accurate indication of the 'general' earning level. The median value for Dar es Salaam is USD 5.38 and for Dodoma it is USD 3.28 . 
Table 6.2 Percentiles for daily earnings

\begin{tabular}{lllll}
\hline $10 \%$ & $25 \%$ & $50 \%$ & $75 \%$ & $90 \%$ \\
\hline USD 0.99 & USD 1.97 & USD 3.72 & USD 7.66 & USD 17.51 \\
TZS 2,262 & TZS 4,500 & TZS 8,500 & TZS 17,500 & TZS 40,000 \\
\hline
\end{tabular}

Source: Author's elaboration based on project survey data.

Additionally, large differences between "highest" and "lowest" take-home earnings indicate highly fluctuating incomes. ${ }^{7}$

Micro-trade was the main source of income for the vast majority (94 percent), although 29 percent had a secondary occupation. The largest group (40 percent) were street vendors selling different items such as magazines or sweets, 35 percent were selling cooked foods or snacks, and 15 percent different food items such as fruits or grains. The remaining 10 percent were involved in different service activities such as car washing or shoe shining.

Employment-related benefits like paid maternity leave or work-injury compensation were practically non-existent. This is not surprising, as most micro-traders have no direct employers - only 6 percent consider themselves wage-workers. The majority are own-account workers (78 percent) or micro-enterprise owners with one or two helpers (16 percent). Even though some traders work on commission for larger retailers, they are not in any standard employment relationship. In Tanzanian labour legislation, employment-related social protection is linked to a standard employment relationship and hence does not cover microtraders. This means that micro-traders have to sign up voluntarily and make the full contribution out of their own pockets. Relatedly, as seen from Table 6.1, social insurance enrolment and coverage in the areas of health and pension only cover 20 percent and 22 percent, respectively.

For most of the key characteristics illustrated in Table 6.1, differences between Dar es Salaam and Dodoma were minor, indicating consistency across locations for issues such as educational level or age. The gender profile, however, differed slightly as the sample consisted of 47 percent females in Dar es Salaam but 69 percent in Dodoma. Median wages were lower in Dodoma (3.28 USD) compared to Dar es Salaam (5.38 USD), and similarly, a larger proportion of traders in Dar es Salaam were immigrants to the city ( 75 percent), whereas, in Dodoma, 66 percent were locally born. This might explain why more traders in Dodoma held key assets (land or property) in their family than in Dar es Salaam (48 percent versus 34 percent). Finally, social insurance coverage was markedly higher in Dodoma (31 percent) compared to Dar es Salaam (13 percent) which can be explained by the prevalence of the Community Health Fund (CHF) outside the capital as discussed below.

\section{Access to formal insurance schemes}

Tanzania has three public insurance schemes potentially encompassing informal operators. That is the National Social Security Fund (NSSF), the National 


\section{Lone Riisgaard}

Health Insurance Fund (NHIF), and the CHF which has recently been relaunched as the improved Community health fund (iCHF) under the NHIF (and co-financed by the government) which targets rural populations and people without formal employment.

The survey shows that enrolment in pension schemes is very rare amongst micro-traders as only 1 percent reported participation. This was substantiated by interviews where respondents considered pensions to be out of their reach. The criteria that one has to contribute for 15 years to be eligible for pension under the current NSSF scheme makes it fit poorly with most informal traders who tend to focus more on short term needs.

A total of 19 percent of the micro-traders contributed to official health insurance divided between CHF (12 percent), NHIF ( 5 percent), NSSF ( 1 percent), and other insurance ( 1 percent). Actual coverage (including cases where a spouse or relative is the primary contributor) shows 22 percent coverage with a similar division between the different schemes. This corresponds to the national coverage of 22 percent estimated in Jacob and Pedersen (2018).

Thirteen percent of the respondents who were not currently contributing to an NHIF scheme had previously done so. Common reasons given for exiting were related to leaving a formal job, the quality of the service or the cost. Amongst the 229 persons from the survey who did not contribute, the most common answer was "it is too expensive", followed by "no knowledge about insurance" and "procedures are too complicated". Hence, problems related to costs, procedures, information flows, and retainment inhibit coverage of micro-traders in the existing schemes.

\section{What characterizes micro-traders enrolled in formal insurance schemes compared to non-enrolled traders?}

In order to examine the relations between formal social insurance enrolment and key worker characteristics, we elaborate a test of means (see Table 6.3). Table 6.3 indicates that enrolled traders are more likely than non-enrolled to be members of an association, to live in Dodoma, be female, married, own key assets, have higher education, and to be either own-account or micro-businesses. Nonetheless, when testing these relations using a standard probit model, only the variables assets, secondary education, and location remain significant (see Riisgaard, 2020).

This leads to the conclusion that traders living in Dodoma are more likely than traders living in Dar es Salaam to enrol in formal insurance schemes and that, on average, traders with a house or a piece of land in the family are also more likely to enrol compared to ones without these assets. Finally, traders with secondary education or above are much more likely to enrol compared to traders who have not completed primary education. These findings seem to indicate that official health insurance mainly caters for the segment of informal traders who are already more resilient (in that they are more likely to have assets in the family and have higher education) but also that access to formal health insurance 
Table 6.3 Differences in key workers characteristics by social insurance enrolment

\begin{tabular}{lcccc}
\hline & $\begin{array}{l}\text { Enrolled } \\
\text { Mean }\end{array}$ & $\begin{array}{l}\text { Non-enrolled } \\
\text { Mean }\end{array}$ & $\begin{array}{l}\text { Mean } \\
\text { Difference }\end{array}$ & $T$ \\
\hline Association member & 0.68 & 0.55 & 0.13 & $1.78^{*}$ \\
Sacco/vicoba/kikundi & 0.53 & 0.33 & 0.20 & $2.82^{* * *}$ \\
Work-related association & 0.11 & 0.19 & -0.09 & -1.55 \\
Women/youth/religious & 0.05 & 0.03 & 0.012 & 0.62 \\
Work-related benefit & 0.19 & 0.17 & 0.023 & 0.48 \\
Social cushioning & 0.14 & 0.08 & 0.06 & 1.45 \\
Voice and representation & 0.02 & 0.04 & -0.02 & -0.80 \\
Loans & 0.33 & 0.27 & 0.06 & 0.94 \\
Dar es Salaam & 0.21 & 0.53 & -0.32 & $-4.50^{* * *}$ \\
Dodoma & 0.79 & 0.47 & 0.32 & $4.50^{* * *}$ \\
Gender (male = 1) & 0.26 & 0.49 & -0.22 & $-3.11^{* * *}$ \\
Married & 0.68 & 0.54 & 0.15 & $2.01^{* *}$ \\
Local born & 0.56 & 0.45 & 0.12 & 1.57 \\
Age & 36.98 & 34.32 & 2.66 & 1.61 \\
Mean daily earnings (current & 9.90 & 7.37 & 2.53 & 1.24 \\
$\quad$ USD) & & & & \\
Assets (house and/or land) & 0.61 & 0.37 & 0.245 & $3.45^{* * *}$ \\
Primary incomplete & 0.07 & 0.15 & -0.08 & -1.56 \\
Primary complete & 0.53 & 0.67 & -0.14 & $-2.00^{* *}$ \\
Secondary or above & 0.4 & 0.18 & 0.22 & $3.62^{* * *}$ \\
Wage-worker & 0.04 & 0.06 & -0.03 & -0.76 \\
Own-account & 0.67 & 0.81 & -0.14 & $-2.32^{* *}$ \\
Micro-business & 0.3 & 0.13 & 0.17 & $3.20^{* * *}$ \\
\hline Sorce: Auts & & &
\end{tabular}

Source: Author's elaboration based on the project survey data.

Notes: $\mathrm{N}$ for enrolled $=57, \mathrm{~N}$ for non-enrolled $=229$. ${ }^{*} \mathrm{p}<0.10,{ }^{* *} \mathrm{p}<0.05,{ }^{* * *} \mathrm{p}<0.01$.

is more widespread in Dodoma which is most likely related to the cheaper CHF option available there.

During discussions, little interest was expressed in the CHF scheme or its urban counterpart TIKA as the quality of the service offered was considered poor. Of much more interest was the newly introduced KIKOA scheme. In 2015/2016, the government diversified NHIF to engage the informal economy through the MUTUAL (commonly known as KIKOA) scheme. Under this scheme, members of registered associations in the informal economy with a minimum of 20 members can join (if a minimum of 10 members sign up) for 76,800 TZS per year per person. Dependents can be signed up at the cost of an additional 76,800 TZS per person (NHIF, 2018). Several associations had provided access to this scheme for their members, as discussed later in in the section on association services.

\section{Perception of key challenges}

When asked during interviews what was perceived to be key challenges, problems with authorities which include evictions, confiscation of goods, fines, harassment, and insecurity of trading spaces were the most mentioned. Lack of access 


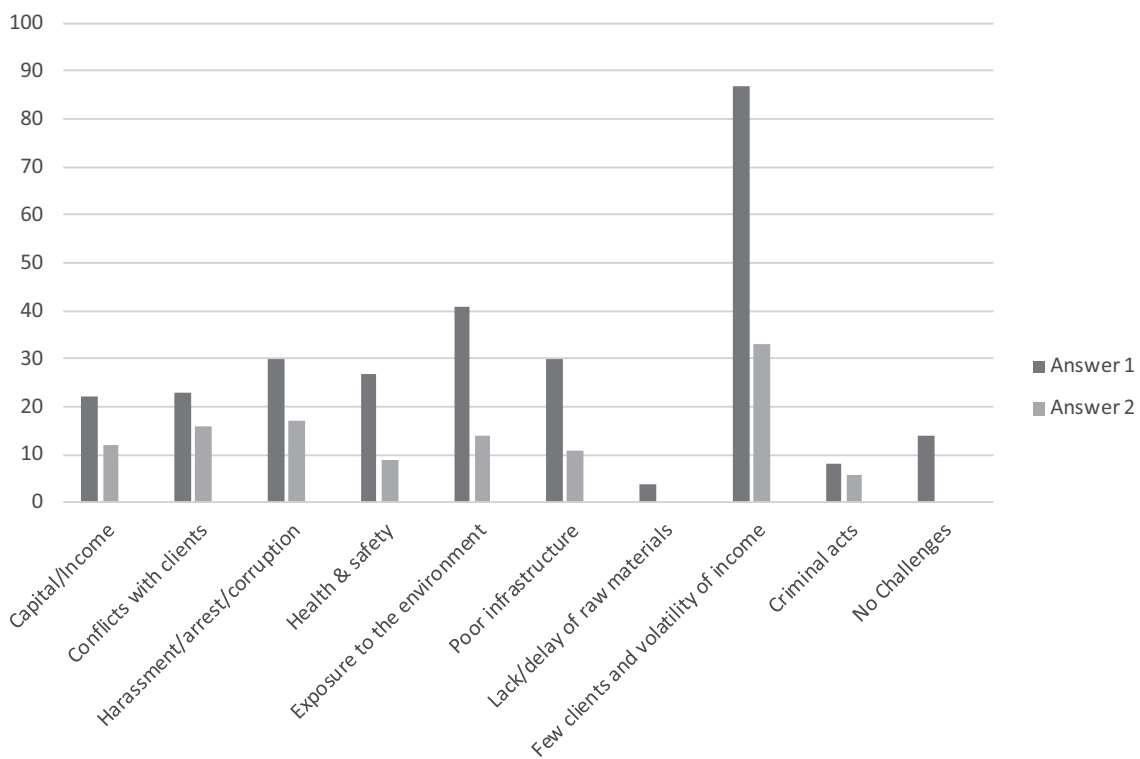

Figure 6.1 Key work-related challenges.

Source: Author's elaboration based on project survey data.

to health insurance, lack of capital, access to credit, and lack of training on business skills were also mentioned as problems.

In the survey, respondents were asked to "Describe the two key challenges/ threats/problems you face in your work". As seen in Figure 6.1, a variety of challenges emerged. Issues related to problems with authorities again come out as important although fluctuations in income was the challenge mentioned most often followed by exposure to the environment.

Survey responses and the qualitative interviews indicate a range of workrelated challenges affecting informal traders, with the most pertinent challenge varying between individual traders. Of particular importance seems to be limited or fluctuating income (which is also evident in the wide differences between low and high daily income estimates reported), exposure to physical conditions, and problems with authorities as well as lack of access to health insurances. As problems with authorities were perceived as an important challenge in both the qualitative and quantitative data, and since this is also related to many of the other challenges the traders face, below, we elaborate on this aspect based on the qualitative interviews.

\section{Relation to the authorities}

Although harassment from authorities was commonly mentioned as a major challenge, there had been some improvements under president Magufuli. 
That the president had publicly made statements in favour of street traders, was noted mainly as a welcome sign of appreciation and a shift from being regarded as a nuisance more than it seemed to have actually changed their daily interactions with local authorities. In addition, trust in the longevity of the current, more positive, climate is limited as noted below:

Although we are out of that mess now since our president Magufuli gave the street vendors the right to perform their activities in Kariakoo market, some of us still do not think that it will be maintained for long so we think maybe someday the system will change and we will go back to the old ways when street vendors were being mistreated and harassed at their business premises.

(KII, Dar es Salaam)

Government actions like evictions can have detrimental effects not just for the individual traders (Skinner, 2008) but also for their associations, as exemplified in the following quote:

Ok as I said before that when we started our group we used to have a lot of good planning but as I said we didn't survive long since the government come to remove us from there so that action destroy a lot of our planning.

(FGD, Dar es Salaam)

Some associations would seek to assist members in case of problems with authorities though most saw themselves as powerless and incapable of helping their members with what they considered harassment by authorities. As noted by Babere (2013), representation towards authorities is furthermore challenged by the fact that numerous different entities are in charge of governing different aspects of informal trade. In the following, we explore in more detail how associations assist their members.

\section{Micro-traders' associations}

Most associations were registered with a constitution guiding their operations. Registration appears to relay a degree of legitimacy in relation to the authorities and in organizing collective support for members such as loans or training. Government promises of loans was frequently mentioned, but rarely materialized. Below, we briefly look at three associations to illustrate some of the variety in terms of organizational set-up and purpose.

\section{VIBINDO society ${ }^{8}$}

Adversarial relations between micro-traders and authorities spurred the establishment of VIBINDO in 1995 when 19 associations formed an umbrella organization to represent their interests and negotiate with authorities in attempts 


\section{Lone Riisgaard}

to secure trading spaces. VIBINDO has since then offered financial services and training for members, established their own private micro-health insurance scheme, and later negotiated the KIKOA scheme with NHIF.

VIBINDO is organized at the national regional and district level and reports more than 60,000 members organized via 630 groups of small businesses. Their mission is "to assist its members in transforming, formalize and grow their micro-businesses and industries in order to enhance opportunities for access to markets, social security, conducive business premises, financial services ..." (Workshop, Dar es Salaam, May 2018).

The membership is predominantly male (80 percent), and while not limited to micro-traders, this group forms the vast majority. Of the micro-traders, the largest part is own-account, although a few have employees. Hence, VIBINDO has more of a private-sector perspective as compared to, for example, the trade unions that focus on the relationships of employment. They are, for instance, members of Tanzania private-sector foundation (TPSF), a private organization lobbying to promote business interest in national policy platforms such as the Tanzania National Business Council (a public private partnership). In addition, VIBINDO focuses on small enterprises rather than wage-workers.

VIBINDO is a well-known name amongst authorities as well as donors and has had several projects with the ILO. In addition to externally funded projects, their source of funding is membership contributions, in addition to offering commercial services like training and assistance in registration of associations.

\section{TUICO ${ }^{9}$}

TUICO has around 80,000 members and is considered one of the better organized and resourced trade unions. In their membership are around 4,000 informal micro-traders and TUICO is an affiliate member of StreetNet International. Their engagement in the informal economy started around 2010 and has been supported by various NGOs.

The branches of informal micro-traders are based in designated markets, as the union has found these informal workers easier to approach. Hence, for practical reasons, access to a somewhat secure vending space is a key consideration for the union when they reach out to informal workers. The implication of this is, however, that they reach the comparatively more secure traders.

A newer initiative from TUICO, originating in an externally funded programme they had with StreetNet International, has been to establish a bargaining committee with two members from each of the market-based branches they have in Dar es Salaam. As noted by a KII in Dar es Salaam, with this initiative, TUICO is seeking to provide a bridge between the municipal authority and traders. This innovative initiative deserves further research, but based on communication with three branch leaders and a handful of branch members, experiences with the committee (as with TUICO more generally) vary from lack of knowledge about the existence of the committee to enthusiasm - as illustrated 
in the quote below by an ordinary member of the Mchikichini branch. TUICO representatives acknowledge the varied receptions of the initiative amongst branches and note that it has been hard to coordinate meetings where more than a handful of representatives show up.

We used to send our problems to local leaders for further steps to be taken because the government start with them but what we came to understand they took our claims to nowhere, so TUICO educated us, we had a committee there because there are some things the government directs but it cannot perform them, so you as business people on your own you need to come together and solve your problems otherwise if you go to market management nothing will be solved, so it needs your committee that will go and discuss the matter with the district director or anyone there.

(FGD, Dar es Salaam)

The quote illustrates what could be argued to potentially be a particular strength of the trade unions, namely the ability to go - and experience with going beyond the particular local market setting. Apart from the issue of representation, TUICO also offered collateral for some of their branches to enable them to secure bank loans and training and seminars on different issues including on entrepreneurial skills.

The approach of TUICO to enrolling members from the informal economy is to incorporate already existing groups of informal workers as union branches. KAVIMCO, for example - a group of traders selling kanga and vitenge in Mchikichini market - became incorporated as a TUICO branch, and all the members enrolled as individual union members under the KAVIMCO branch, with around 60 active members. TUICO leaves it up to the branches to decide how much informal members contribute to the union, as the traditional 2 percent salary deduction is not an option for them. Although the informal economy members do not contribute equally, all union members have equal rights in terms of voting and possibility to be elected to official posts.

\section{Ubindin Street Machinga Association in Dodoma ${ }^{10}$}

This association is quite illustrative of an association where members do not work in a designated trading space. It consists of around 70 micro-traders who work in the same area. There is no membership fee, but a system of contribution where members contribute TZS 2,000 when a member faces problems related to health or death in the family.

The group members previously conducted their business at the Jamatini bus stand where the association was also involved in dividing workspaces amongst the members. Some months back, they were forced to move to a new location, where they were still facing problems with the authorities as stated in the following quote: 


\section{Lone Riisgaard}

we have a lot of trouble from city guard who come to chase us... because this area is not for machinga so we are supposed to leave. For example last week they came to run that operation so during the whole exercise most of our properties are destructed.

(KII, Dodoma)

This experience illustrates common challenges for traders who work in nondesignated spaces. Even if association leaders try to defend their members, they often stand powerless when facing confiscations or forced evictions.

\section{Association focus, rules and entry barriers}

The trader associations encountered in this research appear as a continuum ranging from traders working in a similar location, to those which are larger and more robust organizations based around representation or designated trading locations to those belonging to a larger umbrella structure. Their focus varies from savings and loans over joint business activities to empowerment of women or on representing members towards local authorities.

Although associations vary, in general, limited size and financial resources means that most are vulnerable towards disruptions such as members defaulting. Depending on the accumulated capital and the size and general robustness of the association and its members, defaults might cause the association to collapse. Other challenges are relocation of members and mismanagement of funds by association leaders.

Some groups accept any member who will abide by the association rules, but most are either area or trade-specific. Some groups allowed women only, and most groups had only informal members, although a few like VIBINDO also had members with registered businesses.

Typically, the more financially oriented groups will require the ability to pay a lump-sum entry fee and the ability to save a certain amount weekly or monthly. Other groups focus more on reciprocal participation and contribution, for example, to funerals, marriages, and participation in group meetings. Finally, potential members must often be recommended by an existing member and are assessed for their financial capability and personal qualities like being trustworthy and god-fearing. Hence, it is not always an option for informal traders to become members of a well-functioning group, as noted in the quote below:

I am currently not a member of any group because I have tried to approach some groups but as you know each and every group has not only its specific criteria for an ideal member but also specific established rules and principles so I failed to meet and sometimes to cope with some of those rules and principles.

(FGD, Dodoma)

Groups have rules for excluding members who continually fail to contribute, attend meetings, or repay loans on time although the criteria for exclusion will 
vary between groups. Skinner (2008) when looking at informal traders' organizations has raised concerns about internal group dynamics and about representation by different segments. Although an in-depth analysis of internal dynamics within associations lies outside the scope of our research, we concur that these might not only be guided by the rules laid down in a constitution. Furthermore, the entry barriers to well-functioning groups can well make them out of reach for many traders, something that is important when considering access to social protection through associations.

Below, we discuss micro-traders' associations using the concepts elaborated in the PRA which builds onto the concepts originally conceptualized by Erik Olin Wright of structural power (derived from a worker's position in the economic system) and associational power (derived from the formation of collective organizations of workers) (Schmalz, Ludwig \& Webster, 2018). The PRA was conceptualized to analyse the resources available to formal workers and starts from the basic premise that organized labour can successfully defend its interests by collectively mobilizing different power resources (Schmalz, Ludwig \& Webster, 2018). Nonetheless, a broad reading of the different power resources (as discussed in more detail in Chapter 1) provides a useful tool in comparing and discussing both the actual and potential extent of different forms of power among associations of informal micro-traders.

\section{Associational power}

Based on the sheer magnitude of micro-traders and the rich variety of associational life among them, associational power seems to be potentially highly relevant. Here, the two largest associations TUICO and VIBINDO stand out with regard to their capabilities in representing member interest.

Brown et al. (2015), looking at the large evictions taking place in 2007, found VIBINDO and TUICO to have been co-opted by the establishment resulting in restricted ability to protect traders from eviction. Our research adds to this view a more varied image, where viewpoints among members range from seeing membership of the umbrella organizations as very useful to seeing it as irrelevant. Hence, our data indicate some potential in umbrella structures as VIBINDO and TUICO have been able to offer support to their affiliated groups such as access to training and representation towards the authorities. In fact, in most cases, where associations were found to have facilitated access for their members to external services (loans, training, health insurance) they were in an umbrella structure. However, in general, most associations worked on their own.

\section{Institutional power}

Within the PRA, institutional power derives from laws, regulations, procedures, and practices that regulate the relationship between worker associations and employers to facilitate social dialogue (Schmalz, Ludwig \& Webster, 2018). In the case of informal traders, the relationship between associations and authorities is of key importance. Besides a few designated markets, the institutional set-up 


\section{Lone Riisgaard}

at local and national level does not include representation of informal traders except in an ad-hoc manner. Thus, in the context of micro-trade, sources of institutional power could potentially be advanced by tapping into established tripartite structures via affiliation with trade unions (at government level) and more informally tapping into the access to authorities that trade unions have at more local levels as was the case with the bargaining committee mentioned earlier. A similar potential to access the political and administrative system seemed to be in place for VIBINDO-affiliated associations, as observed by the leader of an association of coconut sellers:

Sometimes if you have a problem or any kind of challenge with the municipal the leaders they (VIBINDO) can go there to present us ... If you face the big problem you can call the VIBINDO, or come to the office to tell them this is too big for us please support us.

(KII, Dar es Salaam)

VIBINDO was also the only informal economy counterpart to NHIF in negotiating the KIKOA scheme and hence seem to have at least some access to authorities at the national level even if this is largely ad-hoc and based on personal connections.

Another form of institutional power is available to associations of members who trade in a local government-sanctioned location. Organizations which have control over their spaces and official government recognition for managing that space have legitimacy and procedures to represent their members towards market management (whether public or private). Registered associations, where members do not have a sanctioned location of trading on the other hand, are threatened by harassment and eviction. However, the power that comes with control over space is potentially time limited as a sanctioned trading place might not continue to be sanctioned under changing political leadership.

\section{Societal power}

Societal power arises from cooperation with other social groups and organizations (coalitional power) and from society's support for the demands put forward by workers (discursive power). Among micro-traders, coalitional power is seen in alliances with organizations of other types of informal workers, with trade unions, other civil society organizations, and with foreign or international NGOs and development actors. For both TUICO and VIBINDO, support from external organizations such as foreign NGOs figured prominently.

Although the informal economy, in general, and the micro-trade sector, in specific, is poorly coordinated, recently, a few attempts at broader coalitions and cooperation between different types of associations have taken place - albeit with limited success (see Riisgaard, 2020). In other countries where micro-trader associations have succeeded in influencing legislative changes towards rights and inclusion, this has most often come about either through a change in urban 
planning policies towards decentralization and participation (Skinner, 2008) or through extensive mobilization, coordination, and organization of microtraders (Kumar \& Singh, 2018). However, currently decentralized and inclusive planning has little political clout in Tanzania. Furthermore, the potential power that could be harnessed through the second strategy of mass-mobilization is so far left largely unexploited. A cause for some optimism is perhaps that the two largest associations TUICO and VIBINDO have signed an MOU which outlines possible areas of cooperation, although, in practice, it is yet to be implemented (KII, Dar es Salaam). This illustrates the recent tendency of trade unions proactively seeking to extend cooperation with associations of informal workers and at the same time extend their constituency. TUICO has, for example, joined StreetNet International in order to advance their representation of informal micro-traders.

Discursive power, which describes the power to successfully influence public discourses and public opinion, is not very strong in Tanzania as micro-traders are still widely seen as a nuisance and in need of formalization. However, some interesting processes can be observed relating to discursive power if understood broadly as different framings of informal traders. The favourable utterances by president Magufuli, for example, have, in a top-down manner, been shaping public discourses on micro-traders in Tanzania and might, if continued, result in increased societal power.

Another process relates to how the associations representing informal traders frame their constituency. The associations studied as part of this research ranged from viewing their members as workers - this was most prominent among the trade unions - to identifying their members as small entrepreneurs. The latter was prominent in VIBINDO which sees itself as a business association.

The framing has consequences for the kind of services and social protection that is deemed relevant for micro-traders. When framed as small businesses like VIBINDO does, emphasis is on issues like skill training, access to finance, and a conducive business environment. With regard to social insurance, emphasis is on tailor-made contributory schemes like the KIKOA. Social protection is framed largely as risk management coupled with services aimed at the business challenges of informal traders.

Another framing of micro-traders is as workers, as done by TUICO, in line with the ILO focus on decent work for all. The trade union approach in Tanzania is still uncoordinated. Thus, there is no consolidated pressure from the union federation on the government to guarantee decent work for informal workers. At the individual union level, TUICO is framing informal traders as sector-specific workers in need of representation towards the authorities.

The micro-traders commonly considered themselves as small entrepreneurs or as small business owners, while across public policies, they are commonly considered self-employed business owners. This is in line with a focus on a modern market-driven economy and frames social protection in quite a minimalist or risk management related way. Hence focus is on contributory schemes and business facilitation (via formalization) and not on employment-related rights or union representation. 


\section{Lone Riisgaard}

\section{Services offered by micro-traders' associations}

As seen from Table 6.4 , the majority ( 63 percent) of traders belonged to an association that they would categorize as Sacco/Vicoba/Kikundi which means that it is either related to savings and loans or support for death or health-related issues in the family. ${ }^{11}$ About one third (30 percent) belonged to what they classify as work-related associations. As the Sacco/Vicoba/Kikundi category is not very differentiated, we also characterized association types based on what members thought was the key benefit they received from being a member. As seen in Table 6.4, this showed a similar pattern, although 49 percent mentioned loans as the main benefit, whereas 16 percent mentioned social cushioning. Voice and representation was mentioned as one of the most important benefits in Dar es Salaam only.

Roever (2014), studying street traders in 10 cities, identified three issues which membership-based organizations help with: (1) mediation with local authorities; (2) information and training; and (3) resolving conflicts among traders (Roever, 2014 , p. 43). Skinner (2008), in her literature review, finds informal traders associations to focus mainly on financial services, lobbying, and advocacy. Our findings indicate that informal social insurance in case of health-related problems or death in the family should be added to the list.

Table 6.4 Key worker characteristics, association members

\begin{tabular}{|c|c|c|c|c|c|c|c|}
\hline & \multicolumn{3}{|c|}{ Tanzania $N=166$} & \multicolumn{2}{|c|}{$\begin{array}{l}\text { Dar es Salaam N } \\
=74\end{array}$} & \multicolumn{2}{|c|}{ Dodoma $N=92$} \\
\hline & Sum & Mean & $\begin{array}{l}\text { Std. } \\
\text { Deviation }\end{array}$ & Mean & $\begin{array}{l}\text { Std. } \\
\text { Deviation }\end{array}$ & Mean & $\begin{array}{l}\text { Std. } \\
\text { Deviation }\end{array}$ \\
\hline $\begin{array}{l}\text { Formal insurance } \\
\text { enrolment (health/ } \\
\text { pension) }\end{array}$ & 39 & 0.23 & 0.43 & 0.09 & 0.30 & 0.35 & 0.48 \\
\hline \multicolumn{8}{|l|}{ Association type } \\
\hline $\begin{array}{l}\text { Sacco/Vicoba/ } \\
\text { Kikundi }\end{array}$ & 105 & 0.63 & 0.48 & 0.54 & 0.50 & 0.71 & 0.46 \\
\hline Work-related & 50 & 0.30 & 0.46 & 0.41 & 0.49 & 0.22 & 0.42 \\
\hline $\begin{array}{l}\text { Women/youth/ } \\
\text { religious }\end{array}$ & 11 & 0.07 & 0.25 & 0.05 & 0.23 & 0.08 & 0.27 \\
\hline \multicolumn{8}{|l|}{ Benefit type } \\
\hline Work-related & 49 & 0.30 & 0.46 & 0.34 & 0.48 & 0.26 & 0.44 \\
\hline Social cushioning & 26 & 0.16 & 0.37 & 0.14 & 0.34 & 0.17 & 0.38 \\
\hline $\begin{array}{l}\text { Voice and } \\
\text { representation }\end{array}$ & 10 & 0.06 & 0.24 & 0.14 & 0.34 & 0.00 & 0.00 \\
\hline Loans & 81 & 0.49 & 0.50 & 0.39 & 0.49 & 0.57 & 0.50 \\
\hline Barriers $($ yes = 1) & 83 & 0.5 & 0.50 & 0.47 & 0.50 & 0.52 & 0.50 \\
\hline $\begin{array}{l}\text { Association fee } \\
\quad(\text { yes }=1)\end{array}$ & 124 & 0.75 & 0.44 & 0.77 & 0.42 & 0.73 & 0.45 \\
\hline
\end{tabular}

Source: Author's elaboration based on the project survey data. 
Table 6.4, however, shows that about half of the associations were reported to have barriers for joining the association. While the other half were reported not to have any entry barriers, nonetheless, they might still require regular cash contributions. In fact, 75 percent of association members had to pay a membership fee to their association and 40 percent were required to pay additional regular contributions. ${ }^{12}$

Most of the services offered by associations can be seen as a form of informal social protection. Based on the qualitative interviews, a few particular services stand out as being very common. Most frequently mentioned was some form of informal social insurance, which almost all groups offered. This was followed by provisions of small loans, training/knowledge sharing, and representation and voice. In addition to delivering actual services, some associations also provide access to external services such as loans, training, or health insurance.

Members had most often contacted their association for help with negotiating with authorities (see Figure 6.2). This was followed by questions regarding loans, savings, or contributions and help with better terms of employment or for work-related challenges. Asked whether contacting the association helped to resolve the issue, 75 percent said yes and 19 percent answered that it partly helped resolve the issue.

In the following, we organize our discussion of the specific services offered by associations via a typology of social protection elaborated by Devereux and Sabates-Wheeler (2004). They distinguish between four main social protection types: protective, preventive, promotive, and transformative. Protective measures largely overlap with social assistance and, as mentioned, are not covered here. Preventive measures include both formal social insurance programmes' pensions, health insurance and maternity leave, and informal insurance. Promotive measures function to enhance or stabilize income, consumption, and capabilities and include access to finance or training while transformative measures

Which Issues did you contact your association for?

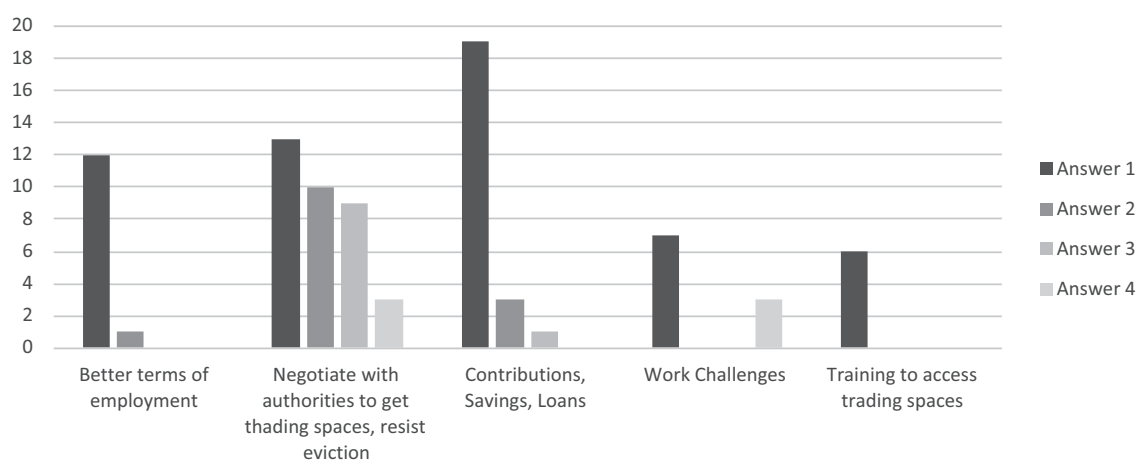

Figure 6.2 What specific issues have you mostly contacted your association about? Source: Author's elaboration based on the project survey data.

Notes: $\mathrm{N}=59$. 
address social equity and exclusion, for example, through collective action and representation.

\section{Preventive measures}

\section{Informal social insurance}

Contributions to cushion against unforeseen needs are very common in Tanzania through different forms of collective association. All participating associations offered some form of social insurance. This ranged from one-off responses to specific problems to more specific insurance schemes. One FGD participant, for example, mentioned that their association paid an amount of money for a caesarean birth but not a 'normal' one, while another group was noted to support celebratory events and minor problems. The extent of such schemes may reflect the financial capability of members as well as the size and robustness of the association. Often, the constitution would detail how much was to be received for what. One group, for example, contributed TZS 100,000 for the death of a father, mother, husband, wife, and children and TZS 50,000 for a niece, nephew, dependent, or brother-in-law (KII, Dodoma). Many groups in addition provide support by showing up for major events or by helping to host them.

No groups provided financial assistance for maternity unless it required hospitalization, but some groups gave three-month maternity leave from group responsibilities and subscription fees.

\section{Associations facilitating access to formal social insurance}

Three of the groups from Dar es Salaam had signed up to the KIKOA scheme, although not all members had subsequently enrolled. Two other groups reported to be in the process of registration, while three associations narrated how they had tried to facilitate access but failed. Several participants had been told that the scheme was about to be reorganized, and at the time of interviews, it was unclear whether the KIKOA scheme was still open for registrations or even functioning. It later became clear that the scheme has since ceased to exist. A representative from the NHIF explained that the KIKOA scheme was challenged by adverse selection, as mainly members with medical needs enrol. This seems to have hampered the roll out of the KIKOA scheme. Nonetheless, the level of interest in and engagement with the KIKOA scheme indicate potential in formal health insurance which works through informal workers associations.

\section{Promotive measures}

\section{Loans for life contingencies or for capital}

The majority of the associations offer some kind of revolving saving and loan function. Hence, 25 percent of the survey sample had received a loan within 
the last 12 months. Of these traders, 70 percent had gotten the loan from their associations, whereas 22 percent had received the loan from private financial institutions such as a bank. ${ }^{13}$

Some of the loans from associations are from the pooled monthly membership contributions and, in other cases, from stock buying. Depending on how much stock a member has bought, the member can borrow three to four times the value of the stocks at a small interest (5-10 percent). While association interest rates were considered very low, the funds available were considered insufficient to meet members' demand.

In sum, it seems that loans obtained via associations are mainly used to smoothen income and cover life contingencies. Access to finance is arguably an important component of the growth of informal micro enterprises - in our survey, 92 percent of the own-account workers expressed interest in growing their business. However, as also noted by Brown et al. (2015), access to finance is only one out of many factors which inhibits growth and thus should not be seen in isolation from other issues such as harassment, conflict over the use of public space, and other insecurities.

\section{Training, knowledge sharing, bulk buying for members, and income generating activities organized through the associations}

Members from nine associations had participated in training provided or facilitated by their associations. Training was mostly on business skills such as training on business management, on how to handle a loan or practical skills such as how to produce items for sale such as batik fabrics or soap.

...for example tomorrow on 29th there's a seminar. We will do it as Uwamata and will give trainings to entrepreneurs for those who will be willing. We will train on how to make handbags, peanuts and soaps making.

(KII, Dar es Salaam)

Knowledge sharing would sometimes turn into joint income-generating activities as was the case with the Amani group in Dodoma which had started out as a group of women helping each other with life contingencies but which had over time developed into undertaking various joint business activities:

So we make the batik fabrics all together and each member gets the end product as batik fabrics to go sell to other people. The member gets to keep the profit but maintains the capital for business until when we meet the following month is when we will make other items.

(KII, Dodoma)

Other promotive measures included associations engaging in bulk buying for members or income generating activities such as renting out tables and pots for functions. 


\section{Lone Riisgaard}

\section{Transformative measures}

About one out of every four associations was involved in some kind of representation of members. The scope and limitations with regard to representation have already been discussed in relation to associational power above, so suffice to emphasize here the importance of this social protection measure for microtraders, as many of the challenges they face are related to problems with the authorities and the lack of recognition, representation, and voice.

One quarter of the associations was for women only. Although this in itself does not guarantee empowerment, sometimes, empowerment of women was an explicit aim. Quite often, helping women, in particular, was part of the reason for forming the groups in the first place. The quote below from a member of a women's only group in Dodoma illustrates how participation can lessen the dependence on husbands:

before we use to depend on our husbands on getting money but they would just leave money for necessary domestic needs, if you get a very little amount of money that's how you're not able of reaching your goals, but now we have groups that we use to support each other, we have started our businesses, you can take-up a loan for business. So far now we don't have too many challenges because at least we get something from our groups, unlike before when we depended on our husbands.

(FGD, Dodoma)

\section{What characterizes members of associations compared to non-members?}

Bromley (2000, p. 14, cited in Skinner, 2008) claims that street trader associations "typically represent older, established and licenced traders". Our results differ somewhat, in part, because the traders we sampled were very unlikely to have a business licence. ${ }^{14}$ In order to examine the relations between association membership and key worker characteristics, we elaborate a test of means (see Table 6.5).

Table 6.5 indicates that association members compared to non-members are more likely to enrol in formal social insurance schemes, to be married, to be older, to be female, not to be wage-workers but have higher education, higher earnings, and own key assets. We note, however, that when testing these relations using a standard probit model (Riisgaard, 2020), only the variables gender, marriage status, age, and earnings remain significant. Hence, we conclude that women are more likely than men to seek out associations, that, on average, members are slightly older than non-members, and married traders are more likely to be members. It could be that the cushioning offered by associations is considered more necessary by traders with family responsibilities. The average higher earnings could point towards members being slightly better off than 
Table 6.5 Differences in key workers characteristics by association member status

\begin{tabular}{lcccc}
\hline & $\begin{array}{l}\text { Members } \\
\text { Mean }\end{array}$ & $\begin{array}{l}\text { Non-members } \\
\text { Mean }\end{array}$ & $\begin{array}{l}\text { Mean } \\
\text { Difference }\end{array}$ & $T$ \\
\hline SI enrolment & 0.23 & 0.150 & 0.085 & $1.778^{*}$ \\
Dar es Salaam & 0.45 & 0.50 & -0.054 & -0.905 \\
Dodoma & 0.55 & 0.50 & 0.054 & 0.905 \\
Gender (male =1) & 0.31 & 0.63 & -0.326 & $-5.769^{* * *}$ \\
Married & 0.69 & 0.39 & 0.301 & $5.297^{* * *}$ \\
Local born & 0.47 & 0.47 & 0.003 & 0.054 \\
Age & 38.02 & 30.46 & 7.566 & $5.976^{* * *}$ \\
Daily earnings (log mean in & 1.49 & 1.26 & 0.230 & $1.775^{*}$ \\
$\quad$ USD)* & & & & \\
Assets (house and/or land) & 0.53 & 0.26 & 0.272 & $4.765^{* * *}$ \\
Primary incomplete & 0.11 & 0.16 & -0.044 & -1.077 \\
Primary complete & 0.62 & 0.67 & -0.046 & -0.801 \\
Secondary or above & 0.27 & 0.18 & 0.09 & $1.797^{*}$ \\
Wage-worker & 0.02 & 0.1 & -0.076 & $-2.784^{* * *}$ \\
Own-account & 0.77 & 0.79 & -0.021 & -0.413 \\
Micro-business & 0.2 & 0.11 & 0.09 & $2.063^{* *}$ \\
\hline
\end{tabular}

Source: Author's elaboration based on the project survey data.

Notes: $\mathrm{N}$ for members $=166, \mathrm{~N}$ for non-members $=120 .{ }^{*}$ Mean daily earnings (current USD) for members equals 8.7599 and 6.4969 for non-members. ${ }^{*} \mathrm{p}<0.10,{ }^{* *} \mathrm{p}<0.05,{ }^{* * *} \mathrm{p}<0.01$.

non-members although we can only speculate as to which way the causality runs. Along with the entry barriers discussed above, these differences should be taken into account when considering access to social protection through associations.

\section{Conclusion}

Public understandings of informal traders as consisting of micro-entrepreneurs, who should be assisted to graduate to formal businesses, have implications for how their access to social protection is perceived. The conceptualization of microtraders as small businesses and not as workers is in sync with the understanding that work-related social protection does not pertain to them, even if they formalize. Micro-traders and other small entrepreneurs are instead envisioned to access social insurance such as health insurance and pensions via contributory schemes.

While enrolment in pension schemes was almost non-existent, public health insurance had become more accessible with the KIKOA scheme which worked through informal workers own associations. Despite adverse selection problems, the interest in and engagement with this scheme points to potential in health insurance schemes tailored to informal workers associations. Our findings indicated that enrolment of micro-traders in public health insurance schemes was not only inhibited by the cost but also lack of knowledge and complicated procedures. The findings furthermore indicate that formal health insurance mainly caters for the segment of informal traders who are already relatively more resilient (i.e. enrolled traders are more likely to have assets and higher 


\section{Lone Riisgaard}

education levels). In sum, existing contributory schemes are out of reach for the majority of micro-traders who have low fluctuating incomes.

The understanding of informality as a transitionary state on the way to formalization also contributes to a general lack of recognition of micro-traders as a group who should have access to representation in their own right. The perspective of people in the informal economy is sometimes addressed in an ad-hoc manner, like, for example, VIBINDO being consulted on the KIKOA scheme. However, there are very few institutionalized spaces where informal traders can directly negotiate as equal social partners, for example, in the design of social protection policies. Hence, when President Magufuli advocated allocation of trading spaces and a stop to harassment of informal traders, this is a benevolent act of the state recognizing their economic contribution and not a result of negotiations between informal traders and authorities.

Although the informal economy, in general, and the micro-trade sector, in particular, is poorly coordinated, the findings show potential in greater coordination to enhance associational power. In most cases, where associations provided representation of members or facilitated access to external services such as loans, training, or health insurance, they were in an umbrella structure. In addition, a few recent attempts at broader coalitions and cooperation between different types of associations have taken place, perhaps pointing towards a future strengthening of associational power. The increasing (although still very limited) incorporation of associations of informal traders into trade unions has to some degree opened up an institutionalized space for representation and voice for informal traders, albeit as part of the trade union movement in the established institutional model, and not as a group who should be represented in their own right. Finally, favourable statements by president Magufuli have in a top-down manner shaped public discourses towards a more favourable view on micro-traders, which could potentially be harnessed by associations to achieve increased societal power.

In general, informal trader associations in Tanzania do not have articulated policies on how informal traders should be represented in social dialogues or what a comprehensive social protection system should look like. Nonetheless, they all in their own way seek to answer to the challenges experienced by their members and provide social protection services which their members cannot access through the formal system.

It is clear from the discussion that informal trader associations offer a wider range of social protection measures than public schemes, most notably, some offer the much-needed transformative measure of voice and representation. In addition, they offer preventive measures in the form of social insurance tailored to the short-term cushioning needs of their members and promotive measures such as savings, loans, training, and joint business activities. While these measures extend only limited coverage, they nonetheless provide services which for most people in the informal economy are difficult or impossible to access elsewhere. In addition to being based on reciprocity, informal social protection among micro-traders is further characterized by being personalized, trust-based, and timely - although also exclusionary in different ways, as entry barriers to 
well-functioning groups can take them out of reach for more vulnerable segments of informal traders.

Overall, the findings underline the importance of taking into account the diversity of informal traders. Not only does their ability to contribute vary widely as seen by the higher occurrence of formal social insurance among traders who have assets and higher education - but so do social protection preferences which differ as women traders, for example, are more likely to prioritize membership of associations as compared to male traders. Along with the entry barriers discussed above, such differences should be taken into account when considering access to social protection through associations.

\section{Notes}

1 The majorety of the micro-traders included in the study were own-account, but wage-workers and micro-enterprise owners with one or two helpers were also included.

2 It is part of a larger research project covering informal transport, construction, and trade in Kenya and Tanzania.

3 Conversion rate $=2221.58$ as of 1 December 2017 .

4 See http://udadisi.blogspot.com/2018/12/is-machinga-identification-equal-to.html [Accessed 7 February 2019].

5 Unless otherwise noted, the average USD rate from June 2018 to December 2018 is used throughout the paper. The rate was $2,284.5$ TZS per USD.

6 Note that 31 percent of all respondents possessed at least two assets, 13 percent possessed at least three assets, and 2 percent possessed at least four assets.

7 Highest $/$ lowest mean $=25,127 / 10,852 ;$ median $=10,000 / 5,000$.

8 Based on two interviews with VIBINDO chairman, with the chairmen of two VIBINDO member groups and with members participating in FGDs as well as secondary literature.

9 Based on interviews with two TUICO officials, a former TUICO representative, representatives from two TUICO branches and several branch members participating in FGDs.

10 Based on interview with deputy chairperson.

11 While Saccos and Vicobas are savings and loan associations registered in a specific way, Vikundi might offer some kind of savings and/or loan function or they might just offer support in case of funerals and hospitalization.

12 The maximum amount reported was 100,000 TZS (44 USD), while the mean was TZS 12,210 (5 USD) and the median TZS 3,000 (1.30 USD).

13 The remainder had received the loan from friends/relatives or from a public institution.

14 Of the own-account and micro-firms participating in the survey, 5 percent had registered their business, 1 percent had a business licence, and 1 percent had both a registration and business licence.

\section{References}

Babere, N.J. (2013) Struggle for space: Appropriation and regulation of prime locations in sustaining informal livelihoods in Dar es Salaam City, Tanzania. PhD thesis. Faculty of Humanities and Social Sciences, School of Architecture, Planning and Landscape, Newcastle University.

Bromley, R. (2000) Street Vending and Public Policy: A Global Review. International Journal of Sociology and Social Policy. 20 (1-2), 1-29. 


\section{Lone Riisgaard}

Brown, A., Lyons, M. \& Dankoco, I. (2009) Street traders and the emerging spaces for urban voice and citizenship in African cities. Urban Studies. 47 (3), 666-683.

Brown, A., Msoka, C. \& Dankoco, I. (2015) A refugee in my own country: Evictions or property rights in the urban informal economy? Urban Studies. 52 (12), 2234-2249.

Brown, A., Mackie, P., Smith, A. \& Msoka, C. (2015) Financial inclusion and microfinance in Tanzania. Inclusive growth: Tanzania country report. Cardiff School of Geography and Planning.

Deacon, B. (2013) Global social policy in the making. Bristol, Policy Press.

Devereux, S. \& Sabates-Wheeler, R. (2004) Transformative social protection. IDS Working Paper 232. Brighton, Institute of Development Studies.

Fisher, G. (2011) Power repertoires and the transformation of Tanzanian trade unions. Global Labour Journal. 2 (2), 125-147.

Hickey, S. \& Seekings, J. (2017) The global politics of social protection. WIDER Working Paper 2017/115. Helsinki, UNU-WIDER.

Hickey, S., Lavers, T., Niño-Zarazúet, M. \& Seekings, J. (eds.) (2019) The politics of social protection in Eastern and Southern Africa. Oxford, Oxford University Press.

ILFS (2015) Integrated Labour Force Survey 2014. Tanzania. Available from: https:// www.nbs.go.tz/tnada/index.php/catalog/31 [Accessed December 2019].

Jacob, T. \& Pedersen, R.H. (2018) Social protection in an electorally competitive environment (2): The politics of health insurance in Tanzania: ESID Working Paper 110. Manchester, UK, The Effective States and Inclusive Development (ESID) Research Centre.

Kumar, S. \& Singh, A.K. (2018) Securing, leveraging and sustaining power for street vendors in India. Global Labour Journal. 9 (2), 135-149.

Lyons, M. \& Msoka, C. (2010) The World Bank and the street: (How) do 'Doing Business' reforms affect Tanzania's micro-traders? Urban Studies. 47 (5), 1079-1097.

Lyons, M., Brown, A. \& Msoka, C. (2014) Do micro enterprises benefit from the 'Doing Business' reforms? The case of street-vending in Tanzania. Urban Studies. 51 (8), 1593-1612.

NHIF (2018) NHIF facts and figures financial year 2017/2018. Available from: http:// nhif.or.tz/uploads/publications/en 1564738202 -NHIF\%20Fact $\% 20$ Sheet $\% 20$ 2017-18-FINAL.pdf [Accessed August 2019].

Riisgaard (2020) Worker organisation and social protection amongst informal petty traders in Tanzania. CAE Working Paper No 4, 2020. Roskilde, Roskilde Universitet.

Roever, S. (2014) Informal economy monitoring study sector report: Street vendors. Cambridge, MA, WIEGO.

Schmalz, S., Ludwig, C. \& Webster, E. (2018) The power resources approach: Developments and challenges. Global Labour Journal. 9 (2), 113-134.

Skinner, C. (2008) Street trade in Africa: A review. Working Paper No 5. WIEGO.

Tripp, A.M. (2000) Political reform in Tanzania: The struggle for associational autonomy. Comparative Politics. 32 (2), 191-214.

Tsuruta, T. (2006) African imaginations of moral economy: Notes on indigenous economic concepts and practices in Tanzania. African Studies Quarterly. 9 (1-2), 103-121. 